the Oakland Housing Authority. "Studies show that youth who have weaker family structures, witness violence in their own families or in their environment, and who have low selfesteem, tend to be joining those gangs. We're fighting those risk factors as hard as we can."

For UCCE, principles employed in $4-\mathrm{H}$, such as hands-on educational activities under the guidance of caring adults, seem ideally suited to after-school enrichment programs.

"What we're doing is exactly what 4-H did 75 years ago when it first started. We're helping communities by helping kids," said Sharon Junge, $4-\mathrm{H}$ youth advisor for Placer and $\mathrm{Ne}$ vada counties.

Junge is an advisor to 4-H SACC, which was started in the 1980s in California as part of the National Cooperative Extension's "Youth at Risk" program. While the after-school program is open to anyone, from 40 to $50 \%$ of participants are considered at risk - poor, abused or neglected, in the program because of a court order, or, increasingly, children with special needs, such as those born with fetal alcohol syndrome, Junge said.

The SACC now serves about 4,700 children aged $\mathrm{K}$-eighth grade in 13 California counties. Sites are located on school grounds. Unlike many other after-school programs, SACC provides up to 10 times as much contact time with adults in structured activities such as hands-on science or arts and crafts projects supervised by 4-H trained adults or teenagers. Some projects focus on basic skills such as learning to prepare snacks, tie shoes or tell time, Junge said.

"People assume (the kids) are getting it at home. Many kids aren't," said Junge, who said they have had students unable to tell time even in the fourth and fifth grade.
In addition, SACC offers children the opportunity to interact with adults in a structured program, sometimes over several years. Some SACC participants have been in the program 5 to 6 years, she said. "You really have a chance to make a difference in these kid's lives."

In a recent survey of SACC sites, including 11 in California, administrators found that SACC programs helped children improve in several areas of their lives - including social interaction, academic performance and cooperative behavior.

The California portion of the survey evaluated 1,138 children aged 4 to14. Those asked to evaluate the students were directly involved in their care, including SACC teachers, classroom teachers and principals. About a third to a quarter of children surveyed were found to have improved socially and academically over the year, with one-third of the students earning better grades. Teachers indicated that they felt about $7 \%$ of students had avoided being held back a grade, which they attributed to SACC involvement. In addition to boosting a child's self-esteem, avoiding grade retention also saves tax dollars. The survey found that the cost of repeating a year of school averaged about $\$ 3,852$ for school districts surveyed.

School-age child care programs such as SACC and ASAP have provided powerful models for UC outreach to underserved communities, and added to the wealth of knowledge being accumulated in the area of child development.

"It demonstrates the benefits of school-age child care on children's health and social and academic behavior," said Joan Bissell, senior lecturer in education at UC Irvine.

\section{Farm programs overhauled}

For the first time in 60 years, U.S. farmers will be able to plant whatever they choose and receive federal payments that are not linked to market prices. On April 4, President Clinton signed into law a $\$ 47$ billion farm bill designed to phase down farm subsidy programs over 7 years.

Under the old system, growers were required to leave a portion of crop land unplanted for supply control. The new program lets farmers grow any commodity, except fruits and vegetables, and continue to receive payments.

In California, the effect of the 1996 Farm Bill will be felt most by rice, wheat, cotton, barley and corn growers, as well as dairy producers. According to the USDA, California rice, wheat and cotton producers received average annual payments of $\$ 78.76$ million, $\$ 21.43$ million and $\$ 78.86$ million, respectively, from 1993 through 1995. (California's dairy farmers do not receive 
direct payments, but receive substantial program benefits through import restriction, marketing regulations, and price supports, according to UC Davis agricultural economist Daniel Sumner.)

While the new farm bill ends the budget assessment on dairy producers, it phases out over 4 years government support for butter, powdered milk and cheese, replacing it with a loan program. Producers of wheat, feed grains, cotton and rice can receive "market transition" payments for 7 years.

"The impact on dairies will be gradual and therefore minimal," says L.J. "Bees" Butler, UC Davis agricultural economist. "It gives people time to adjust. We may eventually see co-ops putting production quotas on producers."

Export subsidies and import barriers remain in place. The Dairy Export Incentive Program remains fully funded until 2002.

The Secretary of Agriculture will consolidate the 33 federal milk marketing orders to between 10 and 14 over 3 years. However, California is authorized to continue its marketing order, including milk standards and pooling provisions.

The 1996 Farm Bill guarantees annual fixed but declining payments to wheat, feed grains, cotton and rice growers, rather than the deficiency payments that have historically varied with market prices. It places a $\$ 36$ billion cap on payments over the next 7 years. Under the old system, farm subsidies would increase dramatically whenever market prices fell. Marketing loan programs will continue with a cap on loan rates for rice, wheat, feed grains, soybeans and other oil seeds and cotton.

Overall the revised farm bill's effect on California will be relatively small, says Sumner, UC Davis economist, because its agricultural industry is less dependent on these federal subsidies than other states.

The Market Promotion Plan has been authorized at $\$ 90$ million and renamed the Market Access Plan. The news here was that the Farm Bill didn't kill the controversial program, Sumner says. The program, which was created to stimulate agricultural exports, is considered by urban interests to be corporate "pork," he says.

The 1996 Farm Bill, also known as the Federal Agriculture Improvement and Reform (FAIR) Act, was initially part of Congress' effort to trim the federal budget, but how much will be saved? Sumner says its hard to tell because the numbers are projections.

"The FAIR act is very likely to cause outlays under basic farm programs and related activities of about $\$ 47$ billion," Sumner explains.
"Last year, when the FAIR was being developed, the Congressional Budget Office (CBO) projected the 1990 Act to cost about $\$ 49$ billion, but some other analysts have said their models suggest that the 1990 Act would have cost less than $\$ 40$ billion over the next 7 years.

"So you could argue that FAIR saved $\$ 2$ billion (as it is scored by CBO) or you could say it will probably cost several billion more than the 1990 Act." (Projected savings plummeted during the drafting of the bill because market prices rose; the initial 7-year cost estimate of the 1990 Farm Bill had been $\$ 57$ billion.)

Although the 1996 Farm Bill calls for significant changes, it does not end farm subsidies in 2002 , says Sumner. "It doesn't say subsidies will drop to zero," he explains. "I think it's unlikely the United States will eliminate farm programs completely in the year 2002, but that depends on the state of policy and politics in 2001."

Anyone who has enrolled in the program or maintained a crop acre base in the last 5 years can sign up for the 7-year contract from May 20 through July 12 .

The 1996 Farm Bill also:

- Establishes a new $\$ 35$ million program for purchasing 170,000 to 340,000 acres of "prime and unique" farmland to limit nonagricultural use of the land.

- Establishes the new environmental quality incentive program authorized at $\$ 200$ million annually, to help crop and livestock producers make environmental and conservation improvements on the farm.

- Reauthorizes federal research programs for 2 years while Congress continues its review.

- Authorizes $\$ 300$ million for the Fund for Rural America for 3 years.

- Reauthorizes through 2002 the Conservation Reserve Program with up to 36.4 million acres of erodible land.

\section{Putah Creek update}

In the Nov.-Dec. 1995 issue of California Agriculture, we reported that lawsuits had been filed to establish rights to the waters of Putah Creek after water diversions for urban and agricultural use caused the lower Putah Creek to dry out and large numbers of its fish to die in 1989. After 6 years of litigation, a Superior Court judge in Sacramento ruled to increase water flows to the creek by about 10,500 acre feet a year roughly a $50 \%$ increase over the current release schedule. Plaintiffs had asked that flows be increased by 30,000 acre feet per year. 